\title{
Magmatism in Antarctica and its relation to Zealandia
}

Smellie, J.L. ${ }^{a}$, Martin, A.P. ${ }^{b}$; Panter, K.S. ${ }^{c}$, Kyle, P.R. ${ }^{d}$ and Geyer, A. ${ }^{e}$

${ }^{a}$ School of Geography, Geology \& the Environment, University of Leicester, LE1 7RH, UK; ${ }^{b}$ GNS Science, Dunedin, New Zealand; 'School of Earth, Environment \& Society, Bowling Green State University, Ohio 43403, USA; ${ }^{d}$ Department of Earth and Environmental Science, New Mexico Institute of Mining and Technology, Socorro, NM 87801, USA; ${ }^{e}$ Institute of Earth Sciences Jaume Almera, ICTJA, CSIC, 08028 Barcelona, Spain

\begin{abstract}
Antarctica and Zealandia were once adjacent blocks of Gondwana with a shared magmatic history during the Mesozoic and earlier. This is preserved in (a) shared Palaeozoic and Mesozoic Gondwana plutonism; (b) magmatism associated with syn-Gondwana breakup, including Jurassic-aged dolerite rocks of the Ferrar large igneous province, and igneous intrusions of similar isotopic affinity occurring on both continents coeval with Late Cretaceous rifting of Antarctica from Zealandia. The shared magmatic history continued post-Gondwana breakup through (c) the generation of oceanic crust and (d) eruption of diffuse alkaline magmatic province (DAMP) rocks. The DAMP encompasses magmatism from the Late Cretaceous to present day that shares isotopic and trace element characteristics over a (now) widely dispersed area of the southwest Pacific. This has been ascribed to either a previously contiguous mantle lithosphere with a shared, syn-Gondwana breakup history contributing to volcanic melts or to an isotopically distinct Antarctica-Zealandia asthenospheric mantle domain. The development of the Antarctic ice sheet after $34 \mathrm{Ma}$ resulted in many volcanoes recording ice interactions that reveal many new details of Antarctica's palaeoenvironmental history. Study of the volcanic history of Antarctica helps to advance understanding of the geological history of the region, including once-conjugate continents like Zealandia.
\end{abstract}

Keywords: Gondwana, large igneous province, West Antarctic rift system, New Zealand volcanic geology, alkaline volcanism, pluton 


\section{Introduction}

Magmatism has played an important role in the geological evolution of Antarctica with many similarities to Zealandia. However, today, an ice sheet covers most of the Antarctic landmass in stark contrast to New Zealand. Prior to c. 90 Ma, Antarctica and Zealandia were part of Gondwana. Zealandia is the almost wholly submerged continental landmass that subsided and fragmented after breaking away from Gondwana, leaving New Zealand as its largest fragment exposed above sea level (Mortimer et al. 2017; Fig. 1). Magmatism in Antarctica has occurred in a variety of tectonic settings that have resulted in diverse magma types and eruptive styles (Fig. 2). Some of the volcanism mirrors that occurring in New Zealand, but there are differences. Moreover, the presence of an extensive ice cover in Antarctica, and its interaction with the volcanism, has given rare opportunities to use the volcanic record to understand past environmental conditions. This paper examines the relationship between Antarctic-Zealandia magmatism, which by the nature of past plate reconstruction focuses on Marie Byrd Land and Victoria Land, and the ocean floor between Antarctica and Zealandia.

\section{Geological Setting}

Antarctica and Zealandia were once-conjugate blocks bounding the Pacific margin of Gondwana. Antarctica consists of ancient cratons and orogens with overlying strata in East Antarctica and; continental blocks, magmatic arc rocks and immature sedimentary rocks in West Antarctica (Siddoway 2008; Goodge \& Finn 2010; Veevers 2012). The suture between East and West Antarctica is proposed to approximately intersect beneath the middle of the Ross Sea (Tinto et al. 2019; Fig. 2), so that Victoria Land is underlain by crust with East Antarctic affinities and Marie Byrd Land by West Antarctic crust. Antarctica and Zealandia share a Mesozoic batholithic history with age distribution patterns of West Antarctic plutons comparable to Median Batholith rocks in Zealandia (Weaver et al. 1994; Siddoway 2008; Siddoway et al. 2004; Tulloch et al. 2019).

Trans-continental rifting of Gondwana started in the Early Jurassic (c. $183 \mathrm{Ma}$ ) with a mantle plume that drove the Ferrar and Karoo large igneous provinces (Weaver et al. 1994; Storey \& Kyle 1997). The rapid and short-lived emplacement of large volumes of mafic magma took place as intrusions and lava flows in East Antarctica and small volume dolerite intrusions in New Zealand (Mortimer et al. 1995; Figs 1, 2). Major, mainly rhyolitic explosive activity, which took place on the Antarctic Peninsula (Fig. 2), is unrepresented in New Zealand at that time. Simultaneously with the rhyolitic explosive activity, subduction and related magmatism formed a prominent long-lived continental magmatic arc along the Pacific margin. Subduction in Antarctica ended in the Cretaceous in Marie Byrd Land (Weaver et al. 
1994) and parts of New Zealand (Tulloch and Kimbrough 2003) but continued along the Antarctic Peninsula as a consequence of plate reorganisation (Weaver et al. 1994).

A second episode of rifting took place in the mid-Cretaceous, culminating in the separation of Zealandia from Antarctica (Kula et al. 2007, 2009; Fig. 1). Rare, Late Cretaceous magmatism continued in Marie Byrd Land and southern Zealandia (Dennison and Coombs 1977; Weaver et al. 1992; Scott et al. 2015; Tulloch et al. 2019), but this period is usually regarded as amagmatic in Victoria Land (Jordan et al. 2020). Further rifting between East and West Antarctica became focused in the West Antarctic rift system (WARS). The WARS is a major pan-Antarctic continental rift $3000 \mathrm{~km}$ in length and 750-1000 km wide (Behrendt et al. 1991; Behrendt 1999; Jordan et al. 2020; Fig. 2). From Eocene time, alkaline magmatism became widespread throughout the WARS, including early plutonism in northern Victoria Land and eastern Marie Byrd Land but switched dominantly to volcanism, which has continued to the present-day. Temporally equivalent alkaline volcanism occurred in New Zealand in large polygenetic volcanoes at Dunedin, Banks Peninsula and various volcanic fields (e.g. Auckland, Waiareka Volcanics), seamounts and volcanic islands (Hoernle et al. 2006; Coombs et al. 2008; Timm et al., 2009, 2010; Mortimer, this volume; Scott et al. this volume). The WARS volcanism is characterised by numerous large volcanoes (LeMasurier 1990; Smellie et al. in press) that are related to a mantle plume in Marie Byrd Land and either mantle-edge flow, a mantle plume(s) or lithospheric delamination with asthenospheric decompression melting in Victoria Land and Zealandia (Hole and LeMasurier 1994; Hart et al. 1995, 1997; Timm et al. 2010; Gamble et al. 2018; Panter et al. 2018). Several volcanoes in Antarctica (Fig. 2) are considered to be active. Of these, at least eight (Mt Erebus, Mt Berlin, Mt Takahe, Mt Waesche, Mt Melbourne, Mt Rittmann, The Pleiades, possibly Hudson Mountains) are considered to be active mainly on the basis of dated Holocene eruptions, and three of them (Mt Erebus, Deception Island, Mt Melbourne) even have reported frequent volcanic activity in historical times.

\section{Gondwana magmatism}

Ross Orogen-associated magmatism in Victoria Land has occurred at least between c. 650 $\mathrm{Ma}$ and $492 \mathrm{Ma}$. In southern Victoria Land, rhyolite rocks have been dated at c. $650 \mathrm{Ma}$ (Cooper et al. 2011), calc-alkaline plutons were emplaced during overlapping, but geographically separate, events at c. 550 to $525 \mathrm{Ma}$ (south) and 515-492 Ma (north), which also coincided with alkalic and carbonatitic intrusions in southern Victoria land between c. 550 and $509 \mathrm{Ma}$ (Hagen-Peter and Cottle 2016). In the Central Transantarctic Mountains plutonism is thought to occur in three phases (Goodge et al. 2012). The earliest phase between c. 590 and $555 \mathrm{Ma}$ represents arc development, the middle phase (c. 555 to 515 $\mathrm{Ma}$ ) is syn-tectonic and the youngest phase is mostly post-tectonic between c. 515 and 480 Ma (Goodge et al. 2012). 
The Ross Orogen plutonism is known collectively as the Granite Harbour Intrusive Complex (Cox et al. 2012; Fig. 1) and rocks thought to be equivalent to this have been mapped in New Zealand (Gibson \& Ireland 1996; Allibone et al. 2009a). At least four examples of Cambrian plutonism in New Zealand are thought to equate to Ross Orogen related rocks. One example of granitoid orthogneiss at Kellard Point in Doubtful Sound (Fig. 1) has been dated at $481 \pm 8$ Ma (Gibson \& Ireland 1996), the Jaquiery granitoid gneiss (Fig. 1) has been dated at $492 \pm 9$ Ma (Allibone et al. 2009a), the Pandora Orthogneiss (tonalite) is c. $500 \mathrm{Ma}$ (Allibone et al. 2009b) and the Dead Goat Conglomerate contains a metagranitic clast with a radiometric date of $496 \pm 9 \mathrm{Ma}$ (Gutjahr et al. 2006). The Ross Orogen-related rocks in New Zealand are chronologically equivalent to the latest, post-tectonic phase of plutonism recognised in the Granite Harbour Intrusive Complex. The major element, whole rock chemistry of the New Zealand Jaquiery granitoid gneiss is described as distinctly different from Antarctic Ross Orogen lithologies, with relatively high $\mathrm{Ca}$ and exceptionally low $\mathrm{K}$ for such a siliceous rock (e.g. Allibone et al. 2009a). Comparison with more recently acquired geochemistry, however, shows a high degree of overlap of whole rock trace element concentrations (Martin et al. 2015 and references therein; Fig. 3). In summary, Ross Orogen-related plutonism does form part of the New Zealand basement, with studied New Zealand examples overlapping chronologically and geochemically (trace elements) with rocks in Victoria Land, Antarctica.

In Marie Byrd Land, the basement has been divided into the Amundsen Province and Ross Province (Pankhurst et al. 1998; Fig. 1). Granitoids in the Amundsen Province chronologically and geochemically correlate with rocks in the Zealandia Median Batholith (Fig. 1). Ross Province granitoids are better correlated with Devonian-Carboniferous terranes and suites in Zealandia (Pankhurst et al. 1998; Tulloch et al. 2019; Fig. 1). This is exemplified by a pulse of coeval granitoid magmatism in both the Antarctic Fosdick Mountains and Zealandia Karamea Suite at $370 \pm 1 \mathrm{Ma}$ (Siddoway \& Fanning 2009; Tulloch et al. 2009, 2019). These plutons are a record of subduction-related magmatism of the Phoenix plate.

\section{Gondwana break-up magmatism}

Large igneous province rocks

Gondwana break-up-related magmatism in Antarctica is represented by two major volcanic provinces, one mafic [the Ferrar large igneous province (FLIP)] the other felsic (Chon Aike), which crop out in different areas (Fig. 2). There is no counterpart of the felsic province in New Zealand. However, coeval equivalents of the mafic FLIP are present in New Zealand as the Kirwins Dolerite (Mortimer et al. 1995; Fig. 1), as well as in southern Africa and Tasmania. In New Zealand, the Kirwans Dolerite (c. $1 \mathrm{~km}^{2}$ ) is composed of sills and dykes. It is chemically similar to low-Ti tholeiite rocks and is considered part of the Jurassic-aged FLIP. The FLIP in Antarctica was characterised by intrusion of thick dolerite sills (Ferrar dolerite) 
throughout the Transantarctic Mountains, the large intrusive Dufek Massif and a contemporaneous, similarly-widespread but now much-eroded flood lava flow cover (Kirkpatrick basalts; Fig. 2). The intrusive rocks and lava flows were probably emplaced in less than $0.4 \mathrm{~m} . y$. at c. $183 \mathrm{Ma}$, which is remarkable given that the estimated volume of tholeiitic magma is $>0.5 \times 10^{6} \mathrm{~km}^{3}$ (Burgess et al. 2015). No major feeder dykes or vents have been reported. Conversely, the earliest activity consisted of major phreatomagmatism that erupted from multiple overlapping coalesced maar-diatreme complexes, called phreatocauldrons (White \& McClintock 2001). The mafic volcanism coincided geographically with the locus of a major long-lived sedimentary basin, now represented by the sedimentary Beacon Supergroup, and the volcanism probably completed the infilling of that basin. The eruptions exerted a major environmental impact of global extent and may have been responsible for the Toarcian mass extinction event (Ernst \& Youbi 2017).

\section{Late Cretaceous rift-related plutonic rocks}

Rifting and break-up of Gondwana is typified by a metamorphic core complex in the Fosdick Mountains, Marie Byrd Land (Fig. 1) with exhumation ages between 109 and $102 \mathrm{Ma}$ (Richard et al. 1994; Siddoway 2008; McFadden et al. 2010; Brown et al. 2016). Equivalent metamorphic core complexes related to the separation of Antarctica and New Zealand are observed in Stewart Island, New Zealand as the Sister Shear Zone (Kula et al. 2007, 2009), later named Pegasus ( 89 to 80 Ma; Ring et al. 2015; Fig. 1). The Paparoa Core Complex (Fig. 1 ) is as likely to be associated with separation of New Zealand and Australia (102 to $89 \mathrm{Ma}$; Tulloch \& Kimbrough 1989). Rift-related magmatism associated with the separation of Antarctica and Zealandia is found in Marie Byrd Land (Storey et al. 1999). Australia-New Zealand-Antarctica were undergoing Late Cenozoic separation contemporaneously (e.g. Gaina et al. 1998), and magmatism on the east coast of New Zealand (Weaver \& Smith 1989; Weaver \& Pankhurst 1991a; Baker et al. 1994; Fig. 1) and west coast of New Zealand (Waight et al. 1998; van der Meer et al. 2016) may be related to either Antarctica or Australia rifting, the cessation of subduction or mantle melting beneath the accreted Hikurangi Plateau (van der Meer et al. 2017). A-type granitoids of the Byrd Coast Granite were emplaced between 101 and $95 \mathrm{Ma}$ (Weaver et al. 1992). The equivalent granitoid types in Zealandia are found inboard of the Median Batholith, most probably associated with granite intrusions found on The Snares and the Auckland Islands of southern Zealandia (Scott et al. 2015; Scott and Turnbull 2019; Tulloch et al. 2019; Fig. 1).

\section{Post-Gondwana breakup magmatism}

Oceanic crust

The earliest evidence for a switch to extensional tectonics in New Zealand is at c. $108 \mathrm{Ma}$ (Scott and Cooper, 2006), with Larter et al. (2002) suggesting rifting between Antarctic and Zealandia probably commenced between West Antarctica and the Chatham Rise (south 
Zealandia) at c. 90 Ma. Seafloor spreading commenced near the Bounty Trough (Fig. 1) at c. $85 \mathrm{Ma}$ (Larter et al. 2002; Davy 2006), though the earliest preserved magnetic identification is chron 34y at c. 83 Ma (Wright et al. 2016; Mortimer et al. 2019). Early spreading involved a number of ridge jumps, for example from the Bounty Trough to the margin of Marie Byrd Land. Spreading was asymmetrical and saw the initiation of seafloor spreading between West Antarctica and the Campbell Plateau at chron 33r (83 to $79.1 \mathrm{Ma}$; Larter et al. 2002). This period of oceanic crust formation post c. $90 \mathrm{Ma}$ is amagmatic in Marie Byrd Land and Victoria Land (Jordan et al. 2020) but is associated with intraplate magmatism in Zealandia (Timm et al. 2010; Mortimer et al. 2019). Dredge samples of primitive basalts along the Australian Antarctic Ridge in the area of sea floor between Antarctica and Zealandia (Park et al. 2019) as well as dredge samples from the Adare Basin seamounts (Panter et al. 2018) located in the northern Ross Sea and the Marie Byrd seamounts (Kipf et al. 2014) located in the Amundsen Sea (Fig. 2) have been studied isotopically and are discussed in the following section on diffuse alkaline magmatic province rocks.

\section{Diffuse alkaline magmatic province rocks}

Petrogenesis

Intraplate magmatism found on continental fragments of east Gondwana and the adjacent oceanic lithosphere is grouped together based on age, distribution, volume and similar geochemical and isotopic characteristics as a diffuse alkaline magmatic province (DAMP; Finn et al. 2005). The DAMP encompasses parts of Antarctica, eastern Australia, Tasmania and Zealandia (Fig. 2) and is long-lived, beginning with Late Cretaceous magmatism in New Zealand (Panter et al. 2006) and through the Cenozoic to current activity in Antarctica (e.g. Mount Erebus). In Zealandia, c. 100 Ma magmatism is associated with the Tapuaenuku (Baker et al. 1994) and Mandamus (Weaver \& Pankhurst 1991b) igneous complexes (Fig. 1), the Westland Dike Swarm (van der Meer et al. 2016, 2017), and magmatism around 85-82 Ma and younger is associated with Chatham Island (Fig. 1) and eastern Chatham Rise (Grindley et al. 1977; Panter et al. 2006). Large, polygenetic volcanoes occur at Dunedin, Banks Peninsula and the Campbell Plateau (Auckland, Campbell and Antipodes islands), with smaller volume $\left(<100 \mathrm{~km}^{2}\right)$ volcanic fields, seamounts and volcanic islands occurring elsewhere (Morris 1984; Timm et al. 2009, 2010; Scott et al. 2015; Gamble et al. 2018; Scott and Turnbull 2019; Mortimer \& Scott this volume; Scott et al. this volume). In Antarctica, the Marie Byrd Land Volcanic Group on the eastern WARS rift shoulder is dominated by 19 major volcanoes which penetrate the West Antarctic Ice Sheet (LeMasurier 2013; Panter et al. in press; Wilch et al. in press). Additionally, more than 100 subglacial volcanoes have been identified concentrated along the central-axis of the WARS in Marie Byrd Land (van Wyk de Vries et al. 2018). In Victoria Land, volcanism of the McMurdo Volcanic Group occurs in three regions comprising from north to south the Hallett, Melbourne and Erebus volcanic provinces. Tomographic models show that the upper mantle underlying the DAMP region between East Antarctica and the Australian-Antarctic mid-ocean ridge is 
characterized by slow velocity anomalies (Lloyd et al. 2019). Furthermore, bathymetric data suggest that a lower density upper mantle in this region may be long-lived (c. $100 \mathrm{Ma}$ ) to account for the subsidence history of the Campbell Plateau as Zealandia rifted away from West Antarctica (Sutherland et al. 2010).

A compositional commonality throughout the DAMP has long been recognized and judged to be related to a common mantle source component underlying the once-adjacent continental landmasses (e.g. Coombs et al. 1986; Barreiro \& Cooper 1987; Johnson 1989). The trace-element enrichment and isotopic signatures of the basalts from these Gondwana fragments are similar to mantle sources for ocean island types (OIB) and in particular a contribution from a HIMU-like variety characterized by low ${ }^{87} \mathrm{Sr} /{ }^{86} \mathrm{Sr}$ and high ${ }^{206} \mathrm{~Pb} /{ }^{204} \mathrm{~Pb}$ values. This was the compositional basis for the promotion of sub-lithospheric plume sources for regions within DAMP (Fig. 2) by earlier studies (e.g. McDonough et al. 1985; LeMasurier and Rex, 1989; Kyle et al. 1992; Lanyon et al. 1993; Baker et al. 1994; Weaver et al. 1994). Mantle plumes have been proposed as one cause of Late Cretaceous volcanism in New Zealand (Hoernle et al. 2020) and some Late Cenozoic to on-going volcanic activity in West Antarctica (Hole and LeMasurier 1994; Phillips et al. 2018). The presence of a large mantle plume may explain the distribution and origin of the Marie Byrd Land volcanoes (LeMasurier \& Landis 1996). The similar compositional characteristics of DAMP rocks has also been explained as being sourced from a single large plume head ('superplume') that was introduced beneath Gondwana in the Late Cretaceous or earlier and became a lithospheric reservoir for the later volcanism (Hart et al. 1997; Panter et al. 2000; Kipf et al. 2014). Recently, Park et al. (2019) supported a Late Cretaceous superplume model to account for the isotopic compositions of basalts dredged from the Australian-Antarctic mid-ocean ridge. They envisaged a deep mantle upwelling that has mixed with asthenosphere to create a widespread sub-lithospheric mantle domain sampled by both oceanic and continental volcanism within the DAMP. Alternatively, sources and mechanisms responsible for DAMP volcanism that do not require mantle plume activity have been proposed. These models call for mantle lithosphere that has been metasomatized by incompatible element-enriched fluids and small degree partial melts to promote radiogenic ingrowth of the HIMU-like signature with the melting of the lithosphere being triggered in a variety of ways (e.g. edge-driven mantle flow, translithospheric faulting, lithospheric delamination) to explain magmatism within DAMP (Rocchi et al. 2002; Panter et al. 2006; Sprung et al., 2007; McCoy-West et al. 2010; Martin et al. 2013; van der Meer et al. 2017; Panter et al. 2018; Day et al. 2019; Scott et al. this volume).

\section{Active volcanism}

Active volcanism is widespread in Antarctica (LeMasurier 1990; Smellie et al. in press) and thus similar to New Zealand (e.g. Hopkins et al. 2020). Several large volcanoes are known or inferred to be active in Victoria Land and Marie Byrd Land. Only Mount Erebus (south 
Victoria Land) and Deception Island (the Antarctic Peninsula; Fig. 2) have been observed in eruption (Geyer et al. in press). Erebus contains the world's only permanent convecting lava lake with a phonolite composition. It has been monitored and studied intensively since the early 1970s (Kyle 1994; Oppenheimer \& Kyle 2008). Mount Melbourne and Mount Berlin (Fig. 2) have also been the source of numerous englacial tephra, together with tephra identified with Mount Takahe, Mount Waesche, Mount Rittman and possibly The Pleiades (Lee et al. 2019; Dunbar et al. in press; Fig. 2). Some eruptions of these volcanoes may have the potential to significantly influence global climate, e.g. by accelerating Southern Hemisphere deglaciation (McConnell et al. 2017). In Victoria Land, the scarcity of pyroclastic rocks is probably due to the eruptions being mainly glaciovolcanic and thus poorly preserved (Smellie, in press), but Late Pleistocene-Holocene tephra have been found in marine sediment cores from the Ross Sea (Del Carlo et al. 2015).

\section{Glaciovolcanic sequences}

Both Antarctica and New Zealand record lava-ice interactions studied in a field called glaciovolcanology (Smellie \& Edwards 2016). Glaciovolcanic sequences are recorded at Ruapehu, New Zealand, between c. 51 and 15 ka that indicate extensive interactions between alpine glaciers and andesite-dacite lava flows (Conway et al. 2015). By contrast, in Victoria Land the Cenozoic glaciovolcanic rocks indicate interactions with ice sheets. The latter fall into two main groups. Group I is the most common comprising multiple, mafic 'a'ā lava-fed deltas. Group II includes englacial lava flows and domes (Smellie et al. 2011). The associated glacial cover was generally c. $<250 \mathrm{~m}$; significantly thicker than the alpine glaciers involved with glaciovolcanic sequences at Ruapehu. The combination of geochronology and glaciovolcanology is a powerful technique for palaeoclimate reconstructions that is useful in both Antarctica and New Zealand.

\section{Conclusions}

Antarctica and Zealandia were contiguous in eastern Gondwana prior to rifting at c. $84 \mathrm{Ma}$. Like New Zealand, magmatism has played an important role in the geological evolution of Antarctica. Although volcanism older than c. $200 \mathrm{Ma}$ is present in Antarctica, it is patchily preserved and poorly understood. By contrast, the volcanism younger than c. $200 \mathrm{Ma}$ is well documented and is better understood. A shared magmatic history between Antarctica and Zealandia is evident from preserved Gondwana-aged plutonism, co-occurrence of Ferrar large igneous province (FLIP) rocks in Antarctica and New Zealand and syn-Gondwana breakup plutonism preserved in Marie Byrd Land and Zealandia. Late Cretaceous-Cenozoic intraplate volcanism in Antarctica and Zealandia share isotopic and trace element characteristics within a diffuse alkaline magmatic province (DAMP). The DAMP rocks include at least eight examples of active volcanism in Antarctica, and lava-ice interactions recorded in both Antarctic and New Zealand volcanic rocks are important palaeoclimate proxies. 


\section{Acknowledgements}

The authors thank A. Cooper, J. Gamble and one anonymous reviewer for their helpful reviews and J. Scott for editorial handling. The authors also gratefully acknowledge the funding and logistical support provided by several national Antarctic Organizations over many years, including: Antarctica New Zealand, British Antarctic Survey, Consejo Superior de Investigaciones Científicas (Spain), Korean Polar Research Institute, National Science Foundation (USA) and Programma Nazionale di Ricerche (Italy). This review is a contribution to AntVolc (https://www.scar.org/science/antvolc/home/).

Data availability statement: Data derived from public domain resources

\section{References}

Allibone AH, Jongens R, Scott JM, Tulloch AJ, Turnbull IM, Cooper AF, Powell NG, Ladley EB, King RP, Rattenbury MS. 2009a. Plutonic rocks of the Median Batholith in eastern and central Fiordland, New Zealand: Field relations, geochemistry, correlation, and nomenclature. New Zealand Journal of Geology and Geophysics. 52:101-148.

Allibone, AH, Jongens, R, Turnbull, I, Milan, L, Daczko, NR, DePaoli, M, Tulloch, A. 2009b. Plutonic rocks of Western Fiordland, New Zealand: Field relations, geochemistry, correlation, and nomenclature. New Zealand Journal of Geology and Geophysics. 52:379-415.

Baker IA, Gamble JA, Graham IJ. 1994. The age, geology, and geochemistry of the Tapuaenuku Igneous Complex, Marlborough, New Zealand. New Zealand Journal of Geology and Geophysics. 37:249-268.

Barreiro BA, Cooper AF. 1987. A Sr, Nd and Pb isotope study of alkaline lamprophyres and related rocks from Westland and Otago, South Island, New Zealand. Geological Society of America Special Paper. 215:115-125.

Behrendt, JC. 1999. Crustal and lithospheric structure of the West Antarctic Rift System from geophysical investigations - a review. Global and Planetary Change. 23:25-44.

Behrendt, JC, LeMasurier, WE, Cooper, AK, Tessensohn, F, Tréhu, A, Damaske, D. 1991. Geophysical studies of the West Antarctic Rift System. Tectonics. 10:1257-1273.

Brown, CR, Yakymchuk, C, Brown, M, Fanning, CM, Korhonen, FJ, Piccoli, PM, Siddoway, CS, 2016. From Source to Sink: Petrogenesis of Cretaceous Anatectic Granites from the Fosdick Migmatite-Granite Complex, West Antarctica. Journal of Petrology. 57:1241-1278.

Burgess SD, Bowring SA, Fleming TH, Elliot DH. 2015. High-precision geochronology links the Ferrar large igneous province with early-Jurassic ocean anoxia and biotic crisis. Earth and Planetary Science Letters. 415:90-99.

Conway CE, Townsend DB, Leonard GS, Wilson CJN, Calvert AT, Gamble JA. 2015. Lava-ice interaction on a large composite volcano: a case study from Ruapehu, New Zealand. Bulletin of Volcanology. 77:1-18. 
Coombs, DS, Adams, CJ, Roser, BP, Reay, A. 2008. Geochronology and geochemistry of the Dunedin Volcanic Group, eastern Otago, New Zealand. New Zealand Journal of Geology and Geophysics. 51:195-218.

Coombs DS, Cas RA, Kawachi Y, Landis CA, McDonough WF, Reay A 1986. Cenozoic volcanism in North, East, and Central Otago. In: Smith IEM, editor. Late Cenozoic volcanism in New Zealand. Royal Society of New Zealand Bulletin. 23:278-312.

Cooper, AF, Maas, R, Scott, JM, Barber, AJW, 2011. Dating of volcanism and sedimentation in the Skelton Group, Transantarctic Mountains: Implications for the Rodinia-Gondwana transition in southern Victoria Land, Antarctica. Geological Society of America Bulletin. 123:681-702.

Cottle, JM. 2002. Evolution of a convergent plate margin: A petrological study of Ross Orogeny magmatism in the Carlyon Glacier region, Southern Victoria Land, Antarctica. Unpublished MSc thesis, University of Otago, Dunedin.

Cottle, JM, Cooper, AF. 2006a. The Fontaine Pluton: An early Ross Orogeny calc-alkaline gabbro from southern Victoria Land, Antarctica. New Zealand Journal of Geology and Geophysics. 49:177189.

Cottle, JM, Cooper, AF. 2006b. Geology, geochemistry, and geochronology of an A-type granite in the Mulock Glacier area, Southern Victoria Land, Antarctica. New Zealand Journal of Geology and Geophysics. 49:191-202.

Cox SC. 2019. Release of the continent-wide dataset GeoMAP v.201907. ISAES 2019 : XIII International Symposium on Antarctic Earth Sciences, 22-26 July 2019.

Cox, SC, Parkinson, DL, Allibone, AH, Cooper, AF. 2000. Isotopic character of Cambro-Ordovician plutonism, Southern Victoria Land, Antarctica. New Zealand Journal of Geology and Geophysics. 43:501-520.

Cox SC, Turnbull IM, Isaac MJ, Townsend DB, Smith Lyttle B. 2012. Geology of southern Victoria Land Antarctica. Institute of Geological and Nuclear Sciences 1:250 000 Geological Map 22.1 sheet + 135 p. Lower Hutt, New Zealand. GNS Science.

Davy B. 2006. Bollons Seamount and early New Zealand-Antarctic seafloor spreading. Geochemistry, Geophysics, Geosystems. 7.

Day JMD, Harvey RP, Hilton DR. 2019. Melt-modified lithosphere beneath Ross Island and its role in the tectono-magmatic evolution of the West Antarctic Rift System. Chemical Geology. 518:45-54.

Defant MJ, F. Xu, JF, Kepezhinskas P, Wang Q, Zhang Q, Xiao L. 2002. Adakites: some variations on a theme. Acta Petrologica Sinica. 18:129-142.

del Carlo P, Di Roberto A, Di Vincenzo G, Bertagnini A, Landi P, Pompilio M, Colizza E, Giordano G. 2015. Late Pleistocene-Holocene volcanic activity in northern Victoria Land recorded in Ross Sea (Antarctica) marine sediments. Bulletin of volcanology. 77:36.

Denison, R, Coombs, D. 1977. Radiometric ages for some rocks from Snares and Auckland Islands, Campbell Plateau. Earth and planetary science letters. 34:23-29.

Dunbar NW, Iverson NA, Smellie JL, McIntosh WC, Zimmerer MJ, Kyle, PR. In press. Marie Byrd Land. Volcanology. In: Smellie JL, Panter KS, Geyer A, editors. Volcanism in Antarctica: 200 million years of subduction, rifting and continental break-up, Geological Society of London Memoir.

Elliot DH, Fleming TH. In press. Ferrar Dolerite and Kirkpatrick Basalt Formations II. Petrology. In: Smellie JL, Panter KS, Geyer A, editors. Volcanism in Antarctica: 200 million years of subduction, rifting and continental break-up, Geological Society of London Memoir. 
Ernst RE, Youbi N. 2017. How Large Igneous Provinces affect global climate, sometimes cause mass extinctions, and represent natural markers in the geological record. Palaeogeography, Palaeoclimatology, Palaeoecology. 478:30-52.

Finn CA, Müller RD, Panter KS. 2005. A Cenozoic diffuse alkaline magmatic province (DAMP) in the southwest Pacific without rift or plume origin. Geochemistry, Geophysics, Geosystems. 6(2):Q02005.

Gaina, C, Müller, DR, Royer, J-Y, Stock, J, Hardebeck, J, Symonds, P. 1998. The tectonic history of the Tasman Sea: A puzzle with 13 pieces. Journal of Geophysical Research: Solid Earth. 103(B6):12413-12433.

Gamble, JA, Adams, CJ, Morris, PA, Wysoczanski, RJ, Handler, M, Timm, C. 2018. The geochemistry and petrogenesis of Carnley Volcano, Auckland Islands, SW Pacific. New Zealand Journal of Geology and Geophysics. 61:480-497.

Geyer, A., Pedrazzi, D., Almendros, J., Berracoso,M. López-Martínez, J., Maestro, A., Carmona, E., Álvarez-Valero, A.M. In press. Deception Island. . In: Smellie JL, Panter KS, Geyer A, editors. Volcanism in Antarctica: 200 Million Years of Subduction, Rifting and Continental Break-Up, Geological Society of London Memoir.

Gibson GM, Ireland TR. 1996. Extension of Delamerian (Ross) orogen into western New Zealand: Evidence from zircon ages and implications for crustal growth along the Pacific margin of Gondwana. Geology. 24:1087-1090.

Goodge JW, Finn CA. 2010. Glimpses of East Antarctica: Aeromagnetic and satellite magnetic view from the central Transantarctic Mountains of East Antarctica. Journal of Geophysical Research: Solid Earth. 115(B9).

Goodge JW, Fanning CM, Norman MD, Bennett VC. 2012. Temporal, Isotopic and Spatial Relations of Early Paleozoic Gondwana-Margin Arc Magmatism, Central Transantarctic Mountains, Antarctica. Journal of Petrology. 53:2027-2065.

Grindley GW, Adams CJD, Lumb JT, Watters WA. 1977. Paleomagnetism, K-Ar dating and tectonic interpretation of Upper Cretaceous and Cenozoic volcanic rocks of the Chatham Islands, New Zealand. New Zealand journal of geology and geophysics. 20:425-467.

Gutjahr, M, Bradshaw, JD, Weaver, S, Münker, C, Ireland, T. 2006. Provenance of Cambrian conglomerates from New Zealand: implications for the tectonomagmatic evolution of the SE Gondwana margin. Journal of the Geological Society. 163:997-1010.

Hagen-Peter, G, Cottle, J.M. 2016. Synchronous alkaline and subalkaline magmatism during the late Neoproterozoic-early Paleozoic Ross orogeny, Antarctica: Insights into magmatic sources and processes within a continental arc. Lithos. 262 677-698.

Hart, SR, Blusztajn, J, Craddock, C. 1995. Cenozoic volcanism in Antarctica: Jones Mountains and Peter I Island. Geochimica et Cosmochimica Acta. 59:3379 - 3388.

Hart SR, Blusztajn J, LeMasurier WE, Rex DC. 1997. Hobbs Coast Cenozoic volcanism: implications for the West Antarctic rift system. Chemical Geology. 139:223-248.

Hoernle K, Timm C, Hauff F, Tappenden V, Werner R, Jolis E, Mortimer N, Weaver S, Riefstahl F, Gohl K. 2020. Late Cretaceous (99-69 Ma) basaltic intraplate volcanism on and around Zealandia: Tracing upper mantle geodynamics from Hikurangi Plateau collision to Gondwana breakup and beyond. Earth and Planetary Science Letters. 529:115864.

Hoernle, K, White, JDL, van den Bogaard, P, Hauff, F, Coombs, DS, Werner, R, Timm, C, GarbeSchönberg, D, Reay, A, Cooper, AF. 2006. Cenozoic intraplate volcanism on New Zealand: 
Upwelling induced by lithospheric removal. Earth and Planetary Science Letters. 248(12):350-367.

Hole MJ, LeMasurier WE. 1994. Tectonic controls on the geochemical composition of Cenozoic, mafic alkaline volcanic rocks from West Antarctica. Contributions to Mineralogy and Petrology. 117:187-202.

Hopkins, JL, Smid, ER, Eccles, JD, Hayes, JL, Hayward, BW, McGee, LE, van Wijk, K, Wilson, TM, Cronin, SJ, Leonard, GS, Lindsay, JM, Németh, K, Smith, IEM. 2020. Auckland Volcanic Field magmatism, volcanism, and hazard: a review. New Zealand Journal of Geology and Geophysics. This volume.

Johnson RW. 1989. Intraplate volcanism in eastern Australia and New Zealand. Cambridge, Cambridge University Press.

Jordan TA, Riley TR, Siddoway CS. 2020. The geological history and evolution of West Antarctica. Nature Reviews Earth \& Environment. 1:117-133.

Kipf A, Hauff F, Werner R, Gohl K, van den Bogaard P, Hoernle K, Maicher D, Klügel A. 2014. Seamounts off the West Antarctic margin: A case for non-hotspot driven intraplate volcanism. Gondwana Research. 25:1660-1679.

Kula, J, Tulloch, A, Spell, TL, Wells, ML. 2007. Two-stage rifting of Zealandia-Australia-Antarctica: Evidence from 40Ar/39Ar thermochronometry of the Sisters shear zone, Stewart Island, New Zealand. Geology. 35:411-414.

Kula, J, Tulloch, AJ, Spell, TL, Wells, ML, Zanetti, KA. 2009. Thermal evolution of the Sisters shear zone, southern New Zealand; Formation of the Great South Basin and onset of PacificAntarctic spreading. Tectonics. 28:TC5015.

Kyle PR, editor. 1994. Volcanological and Environmental Studies of Mount Erebus, American Geophysical Union. 162 pp.

Kyle, PR, Moore, J.A, Thirlwall, MF. 1992. Petrologic Evolution of Anorthoclase Phonolite Lavas at Mount Erebus, Ross Island, Antarctica. Journal of Petrology. 33:849-875.

Lanyon, R, Varne, R, Crawford, AJ. 1993. Tasmanian Tertiary basalts, the Balleny plume, and opening of the Tasman Sea (southwest Pacific Ocean). Geology. 21:555-558.

Larter RD, Cunningham AP, Barker PF, Gohl K, Nitsche FO. 2002. Tectonic evolution of the Pacific margin of Antarctica 1. Late Cretaceous tectonic reconstructions. Journal of Geophysical Research: Solid Earth. 107(B12):EPM 5-1-EPM 5-19.

Lee MJ, Kyle PR, Iverson NA, Lee JI, Han Y. 2019. Rittmann volcano, Antarctica as the source of a widespread $1252 \pm 2$ CE tephra layer in Antarctica ice. Earth and Planetary Science Letters. 521:169-176.

LeMasurier WE 1990. Late Cenozoic Volcanism on the Antarctic Plate: An Overview. In: LeMasurier WE, Thomson JW, editors. Volcanoes of the Antarctic Plate and Southern Oceans. Washington, American Geophysical Union. pp. 1-17.

LeMasurier, W. 2013. Shield volcanoes of Marie Byrd Land, West Antarctic rift: oceanic island similarities, continental signature, and tectonic controls. Bulletin of Volcanology. 75(6):726.

LeMasurier WE, Landis CA. 1996. Mantle-plume activity recorded by low-relief erosion surfaces in West Antarctica and New Zealand. Geological Society of America Bulletin. 108:1450-1466.

LeMasurier, WE, Rex, DC. 1989. Evolution of linear volcanic ranges in Marie Byrd Land, West Antarctica. Journal of Geophysical Research: Solid Earth. 94(B6):7223-7236. 
Lloyd A, Wiens D, Zhu H, Tromp J, Nyblade A, Aster R, Hansen S, Dalziel I, Wilson T, Ivins E. 2019. Seismic Structure of the Antarctic Upper Mantle Based on Adjoint Tomography. Journal of Geophysical Research: Solid Earth. doi.org/10.1029/2019JB017823.

Luttinen, AV. 2018. Bilateral geochemical asymmetry in the Karoo large igneous province. Scientific Reports 8:5223. DOI:10.1038/s41598-018-23661-3.

Martin AP, Cooper AF, Price RC. 2013. Petrogenesis of Cenozoic, alkalic volcanic lineages at Mount Morning, West Antarctica and their entrained lithospheric mantle xenoliths: Lithospheric versus asthenospheric mantle sources. Geochimica et Cosmochimica Acta. 122:127-152.

Martin AP, Cooper AF, Price RC, Turnbull RE, Roberts NMW. 2015. The petrology, geochronology and significance of Granite Harbour Intrusive Complex xenoliths and outcrop sampled in western McMurdo Sound, Southern Victoria Land, Antarctica. New Zealand Journal of Geology and Geophysics. 58:33-51.

McConnell JR, Burke A, Dunbar NW, Köhler P, Thomas JL, Arienzo MM, Chellman NJ, Maselli OJ, Sigl M, Adkins JF. 2017. Synchronous volcanic eruptions and abrupt climate change $17.7 \mathrm{ka}$ plausibly linked by stratospheric ozone depletion. Proceedings of the National Academy of Sciences. 114:10035-10040.

McCoy-West AJ, Baker JA, Faure K, Wysoczanski R. 2010. Petrogenesis and origins of mid-Cretaceous continental intraplate volcanism in Marlborough, New Zealand: implications for the longlived HIMU magmatic mega-province of the SW Pacific. Journal of Petrology. 51:2003-2045.

McDonough, WF, McCulloch, MT, Sun, SS. 1985. Isotopic and geochemical systematics in TertiaryRecent basalts from southeastern Australia and implications for the evolution of the subcontinental lithosphere. Geochimica et Cosmochimica Acta. 49:2051-2067.

McFadden, RR, Siddoway, CS, Teyssier, C, Fanning, CM. 2010. Cretaceous oblique extensional deformation and magma accumulation in the Fosdick Mountains migmatite-cored gneiss dome, West Antarctica. Tectonics. 29. doi:10.1029/2009TC002492.

Mellish, SD, Cooper, AF, Walker, NW. 2002. The Panorama Pluton: a composite gabbromonzodiorite, early Ross Orogeny intrusion in southern Victoria Land, Antarctica. In: Gamble, J.A., Skinner, D.N.B., Henrys, S, editors. Antarctica at the close of a millennium. The Royal Society of New Zealand Bulletin, Wellington, pp. 129-141.

Morris, PA. 1984. Petrology of the Campbell Island volcanics, southwest Pacific Ocean. Journal of Volcanology and Geothermal Research. 21:119-148.

Mortimer N, Scott JM. 2020. Volcanoes of Zealandia and the Southwest Pacific. New Zealand Journal of Geology and Geophysics. This volume.

Mortimer N, Parkinson D, Raine JI, Adams CJ, Graham IJ, Oliver PJ, Palmer K. 1995. Ferrar magmatic province rocks discovered in New Zealand: Implications for Mesozoic Gondwana geology. Geology. 23:185-188.

Mortimer N, van den Bogaard P, Hoernle K, Timm C, Gans PB, Werner R, Riefstahl F. 2019. Late Cretaceous oceanic plate reorganization and the breakup of Zealandia and Gondwana. Gondwana Research. 65:31-42.

Mortimer N, Campbell HJ, Tulloch AJ, King PR, Stagpoole VM, Wood RA, Rattenbury MS, Sutherland R, Adams CJ, Collot JJ. 2017. Zealandia: Earth's hidden continent. GSA Today. 27:27-35.

Oppenheimer C, Kyle PR. 2008. Probing the magma plumbing of Erebus volcano, Antarctica, by openpath FTIR spectroscopy of gas emissions. Journal of Volcanology and Geothermal Research. 177:743-754. 
Pankhurst RJ, Weaver SD, Bradshaw JD, Storey BC, Ireland TR. 1998. Geochronology and geochemistry of pre-Jurassic superterranes in Marie Byrd Land, Antarctica. Journal of Geophysical Research: Solid Earth. 103(B2):2529-2547.

Panter KS In press. Antarctic volcanism. Petrology \& tectonomagmatic overview. In: Smellie JL, Panter KS, Geyer A, editors. Volcanism in Antarctica: 200 million years of subduction, rifting and continental break-up. Geological Society of London Memoir.

Panter KS, Hart SR, Kyle P, Blusztanjn J, Wilch T. 2000. Geochemistry of Late Cenozoic basalts from the Crary Mountains: characterization of mantle sources in Marie Byrd Land, Antarctica. Chemical Geology. 165:215-241.

Panter KS, Wilch TI, Smellie JL, Kyle PR, McIntosh WC in press. Marie Byrd Land \& Ellsworth Land II. Petrology. In: Smellie JL, Panter KS, Geyer A, editors. Volcanism in Antarctica: 200 Million Years of Subduction, Rifting and Continental Break-Up, Geological Society of London Memoir.

Panter KS, Blusztajn J, Hart SR, Kyle PR, Esser R, McIntosh WC. 2006. The Origin of HIMU in the SW Pacific: Evidence from Intraplate Volcanism in Southern New Zealand and Subantarctic Islands. Journal of Petrology. 47:1673-1704.

Panter KS, Castillo P, Krans S, Deering C, McIntosh W, Valley JW, Kitajima K, Kyle P, Hart S, Blusztajn J. 2018. Melt origin across a rifted continental margin: a case for subduction-related metasomatic agents in the lithospheric source of alkaline basalt, northwest Ross Sea, Antarctica. Journal of Petrology. 59:517-558.

Park S-H, Langmuir CH, Sims KWW, Blichert-Toft J, Kim S-S, Scott SR, Lin J, Choi H, Yang Y-S, Michael PJ. 2019. An isotopically distinct Zealandia-Antarctic mantle domain in the Southern Ocean. Nature Geoscience. 12:206-214.

Phillips EH, Sims KWW, Blichert-Toft J, Aster RC, Gaetani GA, Kyle PR, Wallace PJ, Rasmussen DJ. 2018. The nature and evolution of mantle upwelling at Ross Island, Antarctica, with implications for the source of HIMU lavas. Earth and Planetary Science Letters. 498:38-53.

Richard S, Smith C, Kimbrough D, Fitzgerald PG, Luyendyk B, McWilliams M. 1994. Cooling history of the northern Ford Ranges, Marie Byrd Land, West Antarctica. Tectonics. 13:837-857.

Riley T, Leat PT. In press. Antarctic Peninsula \& South Shetland Islands II. Petrology. In: Smellie JL, Panter KS, Geyer A, editors. Volcanism in Antarctica: 200 Million Years of Subduction, Rifting and Continental Break-Up, Geological Society of London Memoir.

Ring U, Bernet M, Tulloch A. 2015. Kinematic, finite strain and vorticity analysis of the Sisters shear zone, Stewart Island, New Zealand. Journal of Structural Geology. 73:114-129.

Rocchi S, Armienti P, D'Orazio M, Tonarini S, Wijbrans JR, Di Vincenzo G. 2002. Cenozoic magmatism in the western Ross Embayment: Role of mantle plume versus plate dynamics in the development of the West Antarctic Rift System. Journal of Geophysical Research: Solid Earth. 107(B9):2195.

Scott, JM, Cooper, AF. 2006. Early Cretaceous extensional exhumation of the lower crust of a magmatic arc: Evidence from the Mount Irene Shear Zone, Fiordland, New Zealand. Tectonics. 25. doi.org/10.1029/2005TC001890.

Scott JM, Pontesilli A, Brenna M, White JD, Giacalone E, Palin JM, le Roux PJ. 2020. The Dunedin Volcanic Group and a revised model for Zealandia's alkaline intraplate volcanism. New Zealand Journal of Geology and Geophysics. This volume.

Scott, JM, Turnbull, IM. 2019. Geology of New Zealand's Sub-Antarctic Islands. New Zealand Journal of Geology and Geophysics. 62:291-317. 
Scott, J, Turnbull, I, Sagar, M, Tulloch, A, Waight, TE, Palin, J. 2015. Geology and geochronology of the Sub-Antarctic Snares Islands/Tini Heke, New Zealand. New Zealand Journal of Geology and Geophysics. 58:202-212.

Siddoway C. 2008. Tectonics of the West Antarctic rift system: New light on the history and dynamics of distributed intracontinental extension (invited paper). In: Cooper IK, Barrett $P$, Stagg $H$, Storey B, Stump E, Wise W, editors. Antarctica: A Keystone in a Changing World. Washington, D.C., National Academy of Sciences. pp. 91-114.

Siddoway, CS, Baldwin, SL, Fitzgerald, PG, Fanning, CM, Luyendyk, BP. 2004. Ross Sea mylonites and the timing of intracontinental extension within the West Antarctic rift system. Geology. 32:57-60.

Siddoway CS, Fanning CM. 2009. Paleozoic tectonism on the East Gondwana margin: Evidence from SHRIMP U-Pb zircon geochronology of a migmatite-granite complex in West Antarctica. Tectonophysics. 477:262-277.

Smellie JL, Edwards BE. 2016. Glaciovolcanism on Earth and Mars. Products, processes and palaeoenvironmental significance. Cambridge, Cambridge University Press.

Smellie JL, Rocchi S, Armienti P. 2011. Late Miocene volcanic sequences in northern Victoria Land, Antarctica: products of glaciovolcanic eruptions under different thermal regimes. Bulletin of Volcanology. 73:1-25.

Smellie JL, Panter KS, Geyer A, editors. In press. Volcanism in Antarctica: 200 million years of subduction, rifting and continental break-up, Geological Society of London Memoir.

Smellie, in press. Antarctic volcanism - Volcanology and palaeoenvironmental oveview. In: Smellie JL, Panter KS, Geyer A, editors. Volcanism in Antarctica: 200 Million Years of Subduction, Rifting and Continental Break-Up, Geological Society of London Memoir.

Sprung, P, Schuth, S, Münker, C, Hoke, L. 2007. Intraplate volcanism in New Zealand: the role of fossil plume material and variable lithospheric properties. Contributions to Mineralogy and Petrology. 153:669-687.

Storey B, Kyle P. 1997. An active mantle mechanism for Gondwana breakup. South African Journal of Geology. 100:283-290.

Storey BC, Leat PT, Weaver SD, Pankhurst RJ, Bradshaw JD, Kelley S. 1999. Mantle plumes and Antarctica-New Zealand rifting: evidence from mid-Cretaceous mafic dykes. Journal of the Geological Society. 156:659-671.

Sun S-s, McDonough WF. 1989. Chemical and isotopic systematics of oceanic basalts: implications for mantle composition and processes. Geological Society, London, Special Publications. 42:313-345.

Sutherland R. 1999. Basement geology and tectonic development of the greater New Zealand region: an interpretation from regional magnetic data. Tectonophysics. 308:341-362.

Sutherland R, Spasojevic S, Gurnis M. 2010. Mantle upwelling after Gondwana subduction death explains anomalous topography and subsidence histories of eastern New Zealand and West Antarctica. Geology. 38:155-158.

Timm, C, Hoernle, K, Van Den Bogaard, P, Bindeman, I, Weaver, S. 2009. Geochemical Evolution of Intraplate Volcanism at Banks Peninsula, New Zealand: Interaction Between Asthenospheric and Lithospheric Melts. Journal of Petrology. 50:989-1023.

Timm C, Hoernle K, Werner R, Hauff F, den Bogaard Pv, White J, Mortimer N, Garbe-Schönberg D. 2010. Temporal and geochemical evolution of the Cenozoic intraplate volcanism of Zealandia. Earth-Science Reviews. 98:38-64. 
Tinto KJ, Padman L, Siddoway CS, Springer SR, Fricker HA, Das I, Tontini FC, Porter DF, Frearson NP, Howard SL. 2019. Ross Ice Shelf response to climate driven by the tectonic imprint on seafloor bathymetry. Nature Geoscience. 12:441-449.

Tulloch AJ, Kimbrough DL. 1989. The Paparoa metamorphic core complex, New Zealand: Cretaceous extension associated with fragmentation of the Pacific margin of Gondwana. Tectonics. 8:1217-1234.

Tulloch, AJ, Kimbrough, DL. 2003. Paired plutonic belts in convergent margins and the development of high Sr/Y magmatism: Peninsular Ranges Batholith of Baja California and Median Batholith of New Zealand. Geological Society of America Special Papers. 374:275-295.

Tulloch AJ, Mortimer N, Ireland TR, Waight TE, Maas R, Palin JM, Sahoo T, Seebeck H, Sagar MW, Barrier A and others. 2019. Reconnaissance Basement Geology and Tectonics of South Zealandia. Tectonics. 38:516-551.

Tulloch, AJ, Ramezani, J, Kimbrough, DL, Faure, K, Allibone, AH. 2009. U-Pb geochronology of midPaleozoic plutonism in western New Zealand: Implications for S-type granite generation and growth of the east Gondwana margin. Geological Society of America Bulletin. 121:12361261.

van der Meer, QH, Storey, M, Scott, JM, Waight, TE. 2016. Abrupt spatial and geochemical changes in lamprophyre magmatism related to Gondwana fragmentation prior, during and after opening of the Tasman Sea. Gondwana Research. 36:142-156.

van der Meer QHA, Waight TE, Scott JM, Münker C. 2017. Variable sources for Cretaceous to recent HIMU and HIMU-like intraplate magmatism in New Zealand. Earth and Planetary Science Letters. 469:27-41.

van Wyk de Vries M, Bingham RG, Hein AS. 2018. A new volcanic province: an inventory of subglacial volcanoes in West Antarctica. Geological Society, London, Special Publications. 461:231-248.

Veevers J. 2012. Reconstructions before rifting and drifting reveal the geological connections between Antarctica and its conjugates in Gondwanaland. Earth-Science Reviews. 111:249318.

Waight, T, Weaver, S, Maas, R, Eby, G. 1998. French Creek granite and Hohonu dyke swarm, South Island, New Zealand: Late Cretaceous alkaline magmatism and the opening of the Tasman Sea. Australian Journal of Earth Sciences. 45:823-835.

Weaver S, Pankhurst R. 1991a. A precise Rb-Sr age for the Mandamus Igneous Complex, North Canterbury, and regional tectonic implications. New Zealand journal of geology and geophysics. 34:341-345.

Weaver S, Adams C, Pankhurst R, Gibson I. 1992. Granites of Edward VII Peninsula, Marie Byrd Land: anorogenic magmatism related to Antarctic-New Zealand rifting. Earth and Environmental Science Transactions of The Royal Society of Edinburgh. 83:281-290.

Weaver SD, Smith IEM 1989. New Zealand intraplate volcanism. In: Johnson RW, Knutson J, Taylor SR, editors. Intraplate volcanism in eastern Australia and New Zealand, Cambridge University Press. pp. 157-188.

Weaver SD, Pankhurst RJ. 1991b. A precise Rb-Sr age for the Mandamus Igneous Complex, North Canterbury, and regional tectonic implications. New Zealand Journal of Geology and Geophysics. 34:341-345.

Weaver SD, Storey BC, Pankhurst RJ, Mukasa SB, DiVenere VJ, Bradshaw JD. 1994. Antarctica-New Zealand rifting and Marie Byrd Land lithospheric magmatism linked to ridge subduction and mantle plume activity. Geology. 22:811-814. 
Whalen JB, Currie KL, Chappell BW. 1987. A-type granites: geochemical characteristics, discrimination and petrogenesis. Contributions to Mineralogy and Petrology. 95:407-419.

White JD, McClintock M. 2001. Immense vent complex marks flood-basalt eruption in a wet, failed rift: Coombs Hills, Antarctica. Geology. 29:935-938.

Wilch TI, McIntosh WC, Panter KS. In press. Marie Byrd Land \& Ellsworth Land I. Volcanology. In: Smellie JL, Panter KS, Geyer A, editors. Volcanism in Antarctica: 200 million years of subduction, rifting and continental break-up, Geological Society of London Memoir.

Wright NM, Seton M, Williams SE, Müller RD. 2016. The Late Cretaceous to recent tectonic history of the Pacific Ocean basin. Earth-Science Reviews. 154:138-173.

\section{Figures}

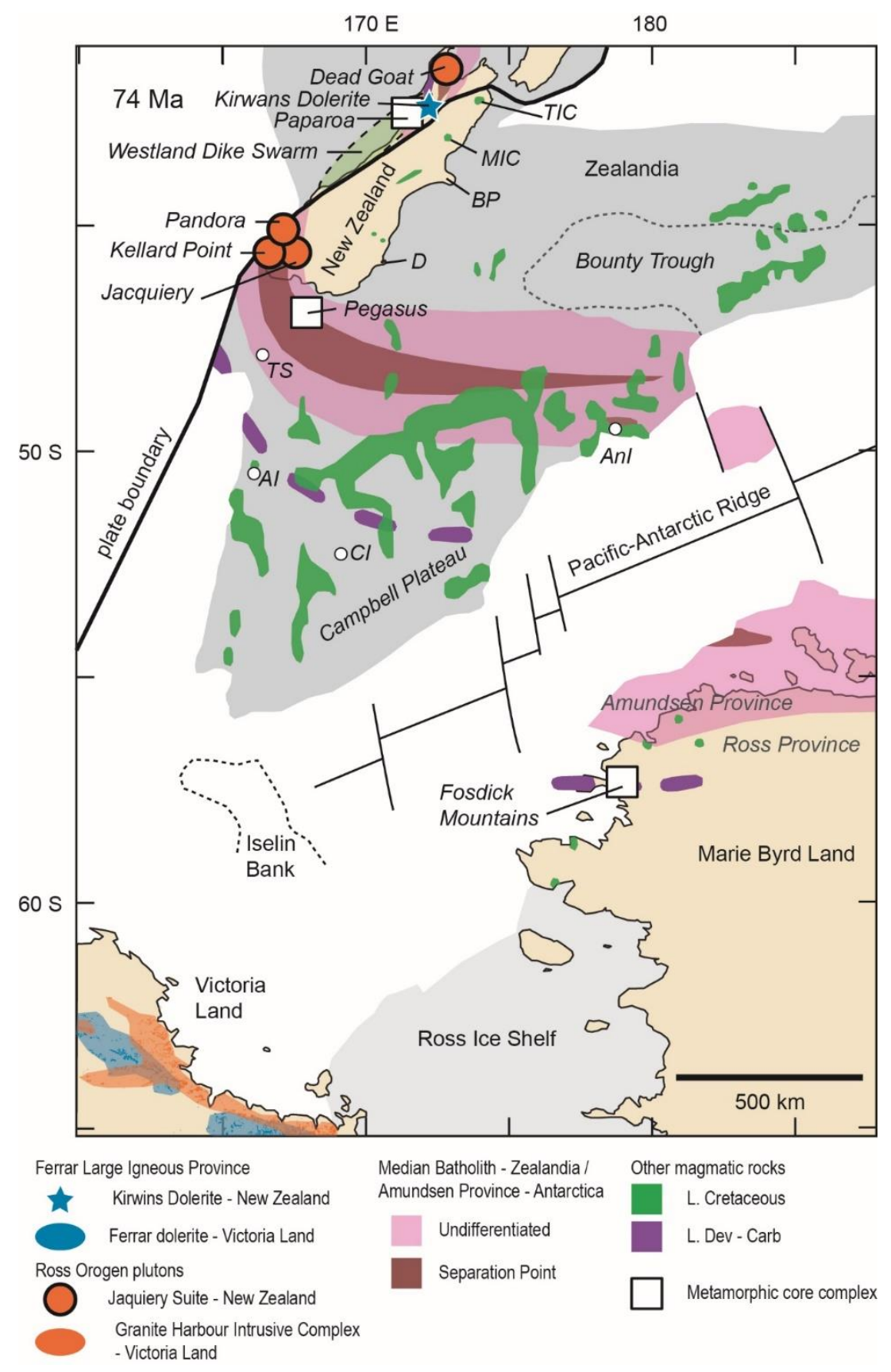


Fig. 1. Schematic diagram showing significant magmatic features shared between Antarctica and Zealandia at c. 74 Ma (adapted from Sutherland 1999; Tulloch et al. 2019). Rock outcrops in Victoria Land (Jurassic magmatic rocks - blue; Cambrian intrusive rocks - orange) are from GeoMap (Cox 2019). Al: Auckland Island; Anl: Antipodes Island; BP: Banks Peninsula; Cl: Campbell Island; D: Dunedin MIC: Mandamus Igneous Complex; TIC: Tapuaenuku Igneous Complex; TS: The Snares.

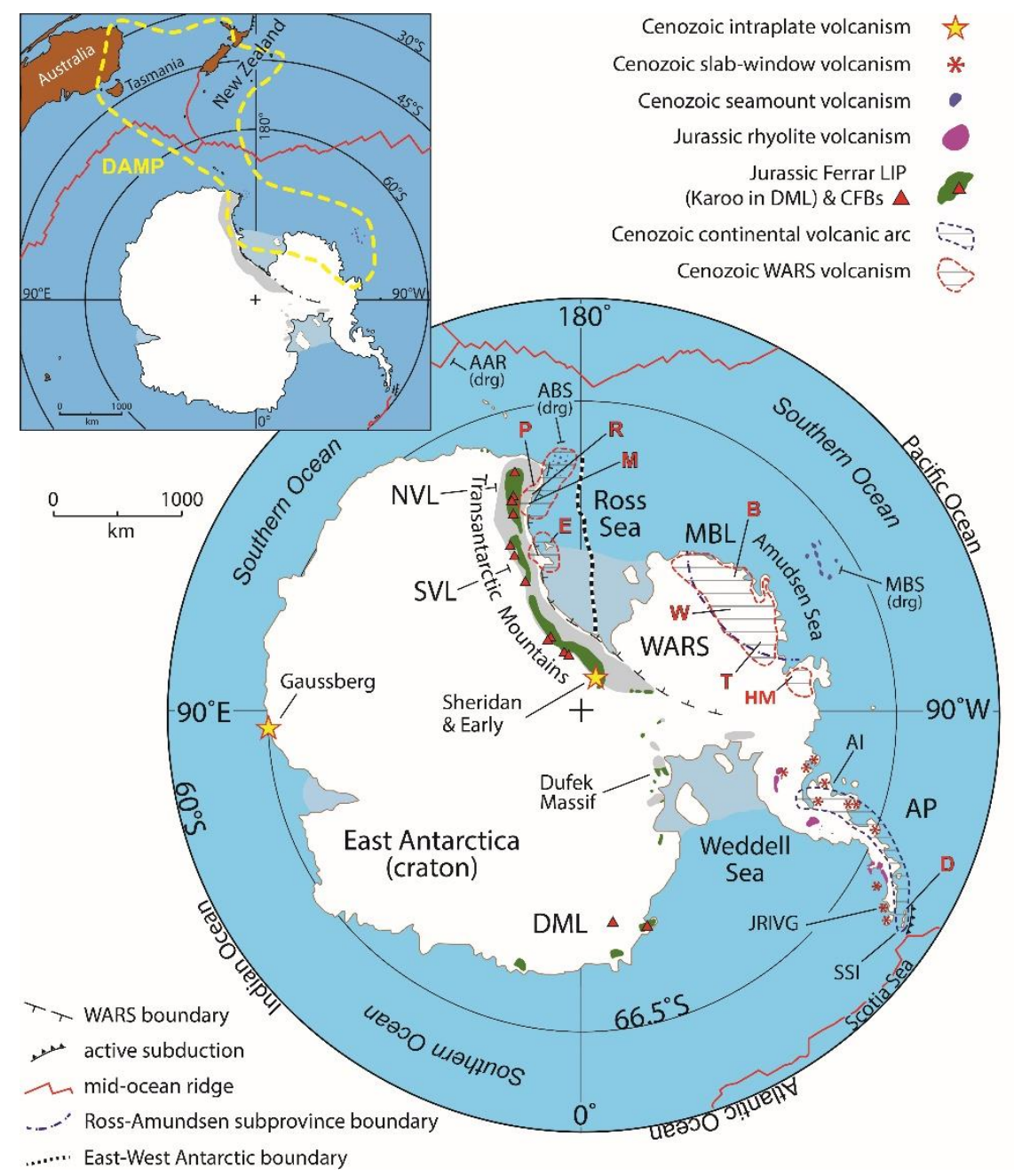

Figure 2. Map of Antarctica showing the distribution of Mesozoic (Jurassic \& Cretaceous) and Cenozoic tectonomagmatic provinces and volcanism (modified after Panter in press). Distribution of Ferrar and Karoo Large Igneous Provinces (LIPs) and associated continental flood basalts (CFBs) after Elliot and Fleming (in press) and Luttinen (2018). Locations of Jurassic rhyolite volcanism are from Riley and Leat (in press). The Ross-Amundsen geotectonic boundary of the West Antarctic Rift System (WARS) is after Jordan et al. (2020) and the geologic boundary between East and West Antarctica is after Tinto et al. (2019) and Jordan et al. (2020). The locations of active volcanoes indicated by bold red letters are $B=$ Mount Berlin, $D=$ Deception Island, $E=$ Mount Erebus, $M=$ Mount Melbourne, $\mathrm{P}=$ The Pleiades, $\mathrm{R}=$ Mount Rittmann, $\mathrm{T}=$ Mount Takahe, $\mathrm{W}=$ Mount Waesche. Other abbreviations are: AAR = Australian-Antarctic Ridge collected by dredging (drg; Park et al., 2019); ABS = Adare Basin Seamounts collected by dredging (drg; Panter et al., 2018); Al = Alexander Island; $A P=$ Antarctic Peninsula; $D M L=$ Dronning Maud Land; $H M=$ Hudson Mountains; JRIVG = James Ross Island Volcanic Group; MBL = Marie Byrd Land; MBS = Marie Byrd Seamounts 
collected by dredging (drg; Kipf et al., 2014); NVL = North Victoria Land; SSI = South Shetland Islands; SVL = South Victoria Land. Cenozoic WARS volcanism in MBL belongs to the Marie Byrd Land Volcanic Group (Wilch et al. in press) and Cenozoic volcanism highlighted in NVL and SVL belongs to the McMurdo Volcanic Group. The latitude of $66.5^{\circ} \mathrm{S}$ is the Antarctic Circle. Inset: dashed yellow line delimits the distribution of intraplate magmatism belonging to the diffuse alkaline magmatic province (DAMP) after Finn et al. (2005).
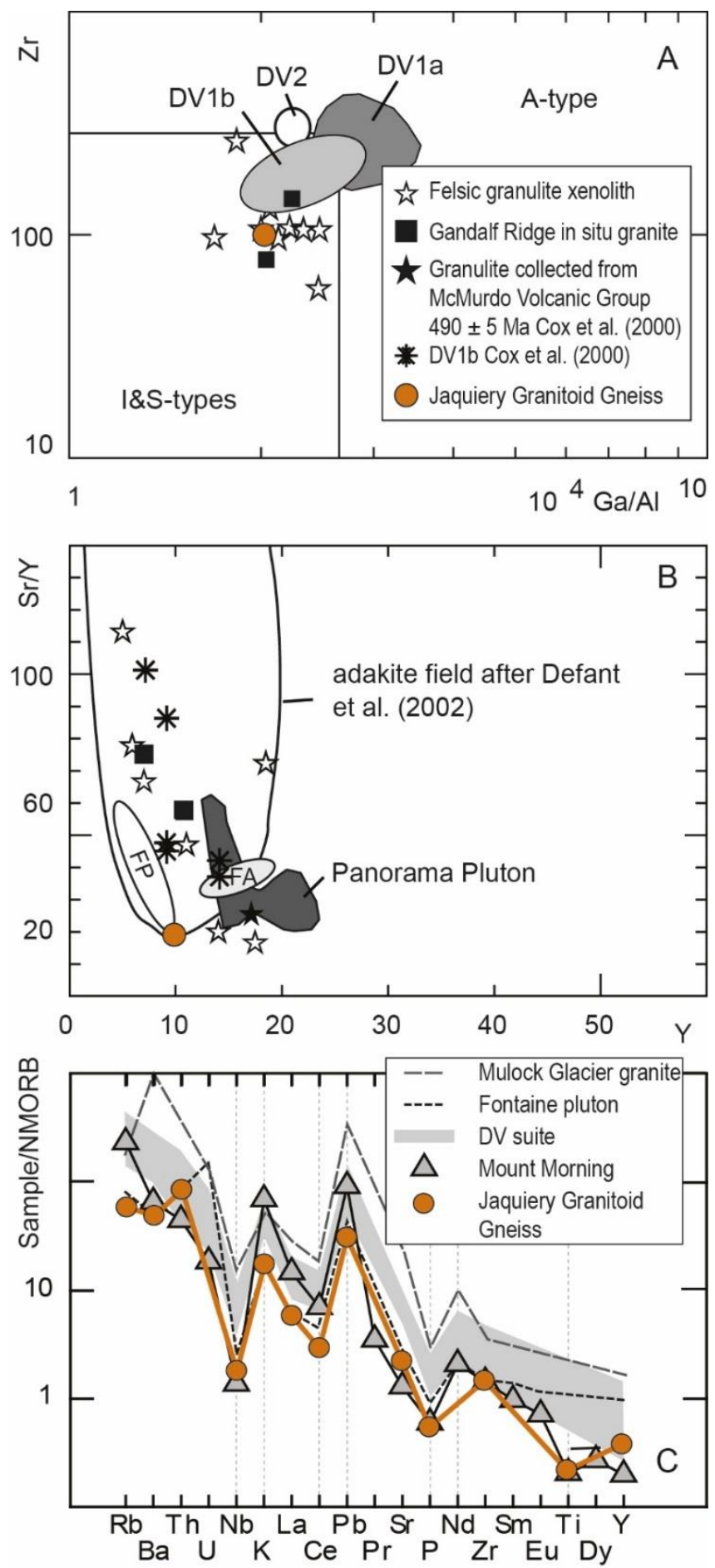
Fig. 3. Whole rock trace element chemistry of Jaquiery granitoid gneiss New Zealand (Fig. 1) relative to select, equivalent Ross Orogen plutonic rocks and xenoliths in Antarctica. The Antarctic comparisons are granulite crustal xenoliths in Cenozoic volcanic rocks in southern Victoria Land (Cox et al. 2000; Martin et al. 2015), the Dry Valleys suites of granites (Cox et al. 2000); granite outcrops at Gandalf Ridge, Mount Morning (Martin et al. 2015); Fontaine Pluton (FP) rocks (Cottle \& Cooper 2006a); Fontaine Adakite (FA) rocks (Cottle 2002); Panorama Pluton rocks (Mellish et al. 2002) and; A-Type Mulock Glacier Granite (Cottle \& Cooper 2006b). A. $10^{4} \mathrm{Ga} / \mathrm{Al}$ versus Zr ppm plot after Whalen et al. (1987) B. Y ppm versus Sr/Y plot with adakite fields from Defant et al. (2002). C. Normal mid-ocean ridge basalt, normalised (Sun \& McDonough 1989) extended element plot. 